Journal of Economics and Behavioral Studies

Vol. 3, No. 6, pp. 337-344, Dec 2011 (ISSN: 2220-6140)

\title{
Psychological Contract and its Relevance in Fast-Food Industry
}

\author{
*Anitha Thomas ${ }^{1}$, Neera Singh ${ }^{2}$ \\ ${ }^{1}$ NIS Academy Alkapur Vadodara, Gujarat, India \\ 2Institute of Management and Technology Rancharda, Ahmedabad Gujarat, India \\ *anitha_tom@rediffmail.com
}

\begin{abstract}
Psychological contracts are defined as the beliefs individuals hold regarding the terms and conditions of the exchange agreement between themselves and their organizations. The study aims at understanding the depth of Psychological contracts at Western Ahmedabad fast-food joints and its relation with employee's commitment. It was indeed a challenge to understand Psychological contracts in this particular sector as its growing at a fast pace and evolving a cutthroat competition. Three Psychological Contract Variables- Relational, Balanced and Transactional were employed on $60 \mathrm{crew}$ member from 7 FastFood Joints. A 16 item Psychological Contract inventory to measure employees' commitment was adopted from PCI of Donald Cable. The study revealed all the three variables in the study, however where commitment was concerned the Dominant one was Transactional commitment. The work concludes with an orientation that, Psychological Contract Variables has lot to do with Lifes'- Orientation of each individual employee.
\end{abstract}

Keywords: Psychological Contract, Employment Relations, Fast-Food Industry, Employee,

\section{Introduction}

The great economic downturn of the year 2009- 2010 was revelation for the industries. The chaos led the stakeholders becoming more vigilant about the question of their sustenance. The sustainability talked not only in terms of PAT and high dividend to the shareholder also but in retention of employee, building up of the knowledge capital and developing a relationship and contract that survives through the thick and thin .Thus came the need to understand the psychological contract which is the base of a long lasting relationship. The psychological contract essentially refers to the mutual expectations people have of one another in a relationship, and how these expectations change and affect our behavior over time. The term is currently used mainly to describe the expectations an employee has of the organization and the expectations the organization has of the employee. The origins of the psychological contract go back thousands of years to the major world religions. One of the most important prayers in the Jewish faith for example, the Amidah, refers to the mutual expectations, in essence the psychological contract, between God and the Jewish people. Amidah (1998) one of the first writers to use the term psychological contract was Argyris who defined it as the implicit understanding between a group of employees and their foreman. "A relationship may be hypothesized to evolve between the employees and the foremen, who might be called the 'psychological work contract' Argyris (1960).

Simply, in an employment context, the Psychological Contract is the fairness or balance (typically as perceived by the employee) between: how the employee is treated by the employer, and what the employee puts into the job. At the heart of the Psychological Contract is a philosophy - not a process or a tool or a formula. This reflects its deeply significant, changing and dynamic nature. The way we define and manage the Psychological Contract, and how we understand and apply its underpinning principles in our relationships inside and outside of work - essentially defines our humanity, respect, compassion, trust, empathy, fairness, objectivity - qualities like these characterize the Psychological Contract, just as they characterize a civilized outlook to life as a whole.

The recent works of PC in the later part of the twentieth century implies on mutuality and reciprocity based on the perceptions of both parties (employee and employer or its agent e.g. managers). The notion of 
mutuality, however can be problematic, especially where there is a large power differential between contractors. This allows for the emergence of multiple psychological contracts, some of which may be rather one-sided rather than mutual, with employees not able to include their expectations and hopes. For example, when employees feel constrained in what they can expect from employers, due to factors such as job insecurity, they may develop what have been termed "compliance contracts" (Smithson and Lewis, 2000). This implies a mutual understanding that employees will do whatever is necessary to retain their jobs. It is a pragmatic response that does not involve loyalty on either side (Smithson and Lewis, 2003). However this perspective of psychological contract is the prospect of further research extending the scope of the present paper.

Content of Psychological Contract: If one attempts to summarize the various research works (Rousseau 1989, 1995, 2000; Levinson et al. 1979 and other), it would be possible to mark out the content of psychological contract. Although, to have a logical conclusion on the content of psychological contract, detailed studies should be undertaken, but still the existing body of knowledge could be used in developing practical implications of psychological contract to business. Davidson (2001) has depicted eight common content elements: benefits/ reward, job security, challenge in the job, working hours, development opportunities, fair treatment, working conditions, work life and work life balance (Davidson, 2001, p 5-7). Analyzing Rousseau's works $(1989,1995$, and 2000) would clearly specify the following as the content of psychological contract: stability, loyalty, state of well-being, external employability, internal advancements, dynamic performance, external employability, internal employability, trust, equitable pay, fairness, and all other related contents.

Types of Psychological Contract: Transactional: The transactional contract is present when the employment arrangement is of a short-term or limited duration, primarily focused exchange of work in lieu of money with a specific and definite description of duties and responsibilities and limited involvement in organization. This is particularly true for employees hired on short-term contracts as well as workers located off-site. Relational: The relational contract results from long-term employment arrangements based upon mutual trust and loyalty. Growth in career and remuneration comes mainly from seniority and other benefits and rewards are only loosely related to work performance. The contract is derived from long term membership and participation in the organization. Balanced: Balanced psychological contract refers to a dynamic and open-ended employment engagement pre-conditioned on business success of the employer organization and the employees' opportunities to develop skill sets and opportunities for career advancement based on skills and performance. Both employee and organization contribute to each other's development. Rewards to workers are based upon performance and contributions to the organization's business success or competitive advantages, particularly in the face of changing business environment.

Psychological Contract and its relevance with employment relations in Fast-Food Industry: The recent resurgence of research interest in the psychological contract stems in large part from the changes and developments that have occurred in the workplace over the past decade or so (Cooper, 1999; Coyle-Shapiro \& Kessler, 2000 pp 903-930; De Meuse \& Tornow, 1990 pp.203-213; Patterson, 2001; Robinson, 1996; Rogers, 1994) and which have, in many ways, placed more emphasis and focus on the individual. These changes and developments are sweeping and have permanently influenced both the individual and the organization. The changes include: increased entrepreneurship; the decline of industrial manufacturing coupled with an increase in the service industries;

From an individual perspective and impact, changes have influenced on the achievement of a personally acceptable work-career balance. Guest (2004, p. 542-544) provided an overview of the many factors impacting on the traditional employment relationship and summarized these as:

- Numbers employed in many workplaces are getting smaller

- Increasing flexibility and fragmentation of the workforce within many establishments

- Pervasiveness and urgency of change

- Growing interest in work-life balance 
- Decline in the proportion of workers who are effectively covered by established systems of consultation and negotiation

- Decline in collective orientation... alongside the growth of individualism.

Additionally, these changes have been paralleled by the move toward a more flexible labour market involving core, contract, and temporary workers (Handy, 1989 pp.41-45). O'Reilly (1994) and Shostak (1993 pp. 3034) discussed a similar fragmentation of the labour market and referred to the core critical intellectual strength of a company (the "top guns"), the regular stable of contract-oriented individuals, plus the parttimers, with the latter often being referred to as the 'just in- time' workforce. These labour market changes have been accompanied by more individual responsibility for self-development and career management, a responsibility increasingly being accepted by individuals. In addition to this Thomas et al (2003) and others proposed that cultural profiles of individual influence the formation of the psychological contract, which leads to a decision making regarding the contract.

Another Major element was the shift: organizational shift from the delivery of a product to the delivery of a service, remuneration has become tied more to market value and less to position and seniority, with the concept of 'job' increasingly being replaced with the concept of 'work' (Bridges, 1994. pp60-74). Bridges (1995, ch7-8) succinctly captured these developments within a historical perspective by proposing that work was transformed from tasks during the industrial revolution in the 18th century, and was then transformed into jobs in the 19th century. The 20th century saw these same jobs transformed into careers, but what is currently being experienced is a reversion back to jobs, and possibly even tasks. Thus emergence of service industry is redefining the whole concept of Psychological Contract.

\section{Literature Review}

The concept of a 'psychological contract' was introduced in 1960 by Argyris. Over the next five years the new concept got much attention from various researches. It received little attention thereafter until the 1990's. The economic downturn led to the restructuring, downsizing, mergers and takeovers in many organizations. That was accompanied by changes in how personnel felt and acted towards their employers. The psychological contract helped explain those changes and, therefore regained attention (Van den Brande, 1999 pp 205-219 cited in Cyril, 2004). In the early definitions of the concept, besides expectations from the individual, the expectations of the organization were incorporated as well. In 1989 Rousseau stated that these expectations are difficult to comprehend as a whole. They can be seen more like a multiple collective of diverse and differing expectations held by a set of actors (Anderson \& Schalk, 1998 pp637-647). Therefore Rousseau (1989) presented a narrower definition with the perspective of the individual as the central element: "Psychological contracts are defined as the beliefs individuals hold regarding the terms and conditions of the exchange agreement between themselves and their organizations." The definition of the Psychological Contract on Wikipedia (April 2010) is: "A psychological contract represents the mutual beliefs, perceptions, and informal obligations between an employer and an employee. It sets the dynamics for the relationship and defines the detailed practicality of the work to be done. It is distinguishable from the formal written contract of employment which, for the most part, only identifies mutual duties and responsibilities in a generalized form."

The pioneer works by Edgar Schein's 1965 describes it as "...there is an unwritten set of expectations operating at all times between every member of an organization and the various managers and others in that organization..." However contemporary works linked PC with many new dimensions. Alexandra and Staffelbach (2011), study assesses the impact of trust in one's employer and employability on the perceived quantitative and qualitative job insecurity of employees who have survived a restructuring. This adds that psychological contract can be applied in lots many instances besides normal functioning like turnaround cases, in restructuring. Another work by Justin and Eisenberger (2003, pp 403), indicate that support theory and psychological contract theory both stress social exchange processes in the establishment and maintenance of the employee-employers relationship, the have focused on different aspects of this 
relationship from being independent to mutually interdependent. Majority of PC work has tried to establish PC's elements in different employment relation. The study on temporary workers by Gossett (2006 pp 385), illustrates some of the control and identification challenges created by this particular work arrangement. This study argues that the coexistence of multiple management systems results in the creation of a loose net of organizational control, which both enables and constrains the actions of temporary workers.

Study Area: The Scope of the study was extended to an Industry where Jobs are short-lived. The relation between Employer and Employee has both individual and collective dimensions. This mean that the relationship is not just dependent on social and economic relationships but beyond a fact, that is it is dependent on culture, law and the economy it operates. TO foster employee loyalty and to keep employees satisfied, the company employees "Individualizing" employee relations. In many HRM programme, employer utilize a general package of measures designed to deliver workplace flexibility, employee involvement, commitment and identification with organizational objectives, the individualization of pay through skillbased remuneration, theoretically allowing the company to deal directly with each individual employee. Therefore, the depth of relationship remains mysterious to each individual working in this industry.

Facts and Figures: Constantly experimenting with the tastes of consumers by mixing western and 'desi' menus, fast food industry has seen a rapid growth in last few years, thanks to high disposable incomes and greater exposure to multiple cuisines. The move to 'localise' the fast food tastes has paid rich dividends and increased brand loyal customer base for the companies. The consumer spending on processed food has increased at an average rate of 7.6 per cent annually from 2008 to 2010 and this is expected to rise at an average of around 8.6 per cent until 2012, according to a report by ASSOCHAM The report indicates a major shift in food habits in metropolitan cities with about 86 per cent of respondent households preferring to have instant food due to steep rise in dual-income levels, standard of living, convenience and influence of Western countries, thus making the sales at fast-food chains growing at a rate of $28 \%$ in India. This being a huge labour Intensive Industry, rather being collective in nature, they focus their people management to be individualistic.

\section{Methodology}

The Sample and Respondent Profile: Seven fast-Food chains of Western Ahmedabad were selected for the study. The sample consisted of 60 purposively selected employees from the crew. Of the total respondents $43 \%$ were in the age group of $20-25$ and $40 \%$ were in the age group of $25-30.43 \%$ of the total sample had $1-2$ year experience and $27 \%$ had 1 year experience. $90 \%$ of respondents have studied till high-school. So more employees are youngsters in the fast food chain industry. Most employees join fast food chain just in starting of their career. Hence its formation years of for them to start understanding any employee relation.

The Instrument: A 16 point questionnaire of Donald Cable was adopted to measure Psychological Contract variables-strength of relational contract, strength of balanced contract, strength of transactional contract, overall satisfaction and overall employees' commitment and obligation with the employer. The questionnaire were divided in four parts

Part-1: Respondents' biographic data

Part-2: eight statements to measure reasons behind joining the industry

Part3: 16 statements to measure employees' Psychological Contract

Part-4: 16 statements to measure overall satisfaction and commitment

Part 3 and part 4 was adopted from the Psychological Contract, developed by Donald (2008). It employs the five-point likert scale. It measures the strength of relational, transactional and balanced contracts and part-4 measures overall satisfaction and commitment, which was improvised to suit the industry. The Cronbach's @ reliability test on Psychological Contract inventory (PCI) for this sample revealed the reliability of 0.75 , hence the instrument used had good reliability. 


\section{Results and Discussion}

Objective 1(a): To understand relationship between age, education and reasons behind joining the Industry. The results for measuring the reason behind their joining the industry led to two interesting revelation, first is that they have joined the industry at the young age and secondly $47 \%$ joined this industry for money, and contrast to it 33\% joined this industry for Career Development. This contrast revelation indicates that the any psychological contract has to do a lot with individual employee's life priorities termed as Life-Orientation.

Objective 1(b): To further understand whether the motive behind joining the industry has been satisfied in terms of PC or not.

Table 1: Correlation between Reason joining the industry and Satisfaction

\begin{tabular}{|c|c|c|c|c|}
\hline & & Satisfaction & $\begin{array}{l}\text { Working for Money, } \\
\text { Interest or Career }\end{array}$ & Overall PC \\
\hline \multirow[t]{3}{*}{ Satisfaction } & Pearson & 1 & -.029 & $.501(* *)$ \\
\hline & Sig. (2-tailed) & & .880 & .006 \\
\hline & & 60 & 60 & 60 \\
\hline \multirow{3}{*}{$\begin{array}{l}\text { Working for } \\
\text { money, Interest } \\
\text { or career }\end{array}$} & Pearson & -0.29 & 1 & 0.14 \\
\hline & Sig. (2-tailed) & .880 & & .943 \\
\hline & $N$ & 60 & 60 & 60 \\
\hline \multirow[t]{3}{*}{ Overall PC } & Pearson & $.501\left(^{* *}\right)$ & 0.14 & 1 \\
\hline & $\begin{array}{l}\text { Correlation } \\
\text { Sig. (2-tailed) }\end{array}$ & .006 & .943 & \\
\hline & $\mathrm{N}$ & 60 & 60 & 60 \\
\hline
\end{tabular}

Study Reveals there is no Correlation or significance $r=-.029$ and .014 significance at .880 and .943 between Working for Money, career or Interest with either satisfaction or overall PC.

Objective 2: To understand employees' commitment and obligation with the organization

$90 \%$ of total sample feels that organization is providing aspiration to them that is why $60 \%$ of the sample wants to spent rest of the career in the same organization. However most employees being satisfied, they do not feel as a part of the family ( $63 \%$ of the sample) in the organization. The reason observed was that they are not given a chance for decision making, and to express their views. That is the reason $43 \%$ of the sample does not feel emotional attachment with the organization. They further emphasized that lack of motivation, lack of leader's transparency; less support for management are the reasons for less emotional attachments. They want to spent their rest of the career, yet don't feel emotionally attached, inspite of another hard hitting fact that $47 \%$ finding hard to leave the organization, even if they want to and $23 \%$ being neutral on it and the same percentage of sample feels that leaving the organization right now, means too much of life would be disrupted. To substantiate it further, $73 \%$ of the sample feels that they have no obligation to remain in the organization.

Content analysis was done using the syntactical units relating to know participants objective and commitment to the organization and their job reveled that there are tree major factors, which prominently featured, are Money, Opportunities and Experience. These do not show divergent relationship but a convergent relationship. This is further proved by the factor analysis. As we find that $43 \%$ are committed but yet not emotionally attached, they want monetary benefit but are also waiting for ideal opportunity and are trying to gain experience ( $47 \%$ are finding it hard to leave the organization) Objective: 3 To understand the strength of balance, relational and transactional PC among the respondents' 
Table 2: Factor Analysis and its item distribution

\begin{tabular}{|c|c|c|c|c|}
\hline $\mathbf{S} / \mathbf{N}$ & Items & Factor 1 & Factor 2 & Factor 3 \\
\hline 1 & $\begin{array}{l}\text { I would be very happy to spend the rest of my career in this } \\
\text { organization. }\end{array}$ & & & .813 \\
\hline 2 & I really feel as if this organization's problems are my own. & .614 & & \\
\hline 3 & I do not feel like "part of the family" in the organization. & & .652 & \\
\hline 4 & I don't feel "emotionally attached" to this organization. & & .814 & \\
\hline 5 & This organization has a great deal of personal meaning to me. & & & .685 \\
\hline 6 & $\begin{array}{l}\text { It would be very hard for me to leave this organization right } \\
\text { now, even if I wanted to leave this. }\end{array}$ & .809 & & \\
\hline 7 & $\begin{array}{l}\text { Too much of my life would be disrupted if; I decided I wanted } \\
\text { to leave this organization right now. }\end{array}$ & .652 & & \\
\hline 8 & $\begin{array}{l}\text { Right now, staying with this organization is a matter of } \\
\text { necessity as much as desire. }\end{array}$ & & & .561 \\
\hline 9 & $\begin{array}{l}\text { One of the few negative consequences of leaving this } \\
\text { organization would be the scarcity of available alternatives. }\end{array}$ & & .554 & \\
\hline 10 & $\begin{array}{l}\text { One of the major reasons I work for this organization is that } \\
\text { another organization may not match the overall benefits I } \\
\text { have here. }\end{array}$ & Nullified & & \\
\hline 11 & I do not feel any obligation to remain with this organization. & & .758 & \\
\hline 12 & $\begin{array}{l}\text { Even if it were to my advantage, I do not feel it would be right } \\
\text { to leave this organization now. }\end{array}$ & .455 & & \\
\hline 13 & I would feel guilty if I left this organization now. & .681 & & \\
\hline 14 & This organization deserves my loyalty. & .370 & & \\
\hline 15 & $\begin{array}{l}\text { I would not leave this organization right now because I have a } \\
\text { sense of obligation to the people in it. }\end{array}$ & .505 & & \\
\hline 16 & I owe a great deal to this organization. & & & .712 \\
\hline
\end{tabular}

The measures of the psychological contract were subjected to reliability (KMO .554 at .000 significance) process involved two steps. The first step, involved item being put to test at Eigen value 1 and second was factor analysis. Factor analysis of the PC Inventory revealed three factors. One factor, termed relational commitment and it is reflected by such statements like: (PCI no.12) Even if it were to my advantage, I do not feel it would be right to leave this organization now This indicates a collective interest between the employee and the organization, Second factor, termed transactional commitment which reflects a self/other interest on the part of the employee, included the items that were believed to be of a more direct employment transactions nature. This factor is seen in statement (PCI no.9) one of the few negative consequences of leaving this organization would be the scarcity of available alternatives. Third, termed as balanced commitment reflects mutual advantage in the employment and statements like: (PCI no.1) I would be very happy to spend the rest of my career in this organization, indicates that the employee would like to be part of the industry for skill development.

Objective 4: To establish relationship between various types of PC and employees' commitment

Table 3: Correlation study between Factors and Satisfaction

\begin{tabular}{lllll}
\hline & & N & Correlation & Sig. \\
\hline Pair 1 & Overall PC \& factor 1 & 60 & .757 & .000 \\
Pair 2 & Overall PC \& factor 2 & 60 & .281 & .140 \\
Pair 3 & Overall PC \& factor 3 & 60 & .757 & .000 \\
Pair 4 & Satisfaction \& factor 1 & 60 & .185 & .337 \\
Pair 5 & Satisfaction \& factor 2 & 60 & .574 & .046 \\
Pair 6 & Satisfaction \& factor 3 & 60 & .185 & .337 \\
\hline
\end{tabular}


Study sates that Overall PC has significance with Pair 1 of Balanced PC (r .757 at .000 significance) and pair-3 of Relational PC ( $\mathrm{r} .757$ at .000 Sig.), least with Transactional PC, however there is a positive significance between Satisfaction and Pair 5 and that indicates that when it comes to satisfaction, they are satisfied due to monetary benefit they are getting, hence proving Transactional PC. They are committed and obliged with their industry till their transactional relations' with their employees are met. To substantiate it further another correlation study with regard to their satisfaction and saving option was administered, it indicated high $\mathrm{r}-.782$ at significance .000

Implication of the Study: The employees join at the young age, that's why their interest is of getting more and more money. Even if they look forward to a career development, then too their prime motive joining the industry is for money. This contrast can lead to another understanding i.e, Life- Orientation. The type of contract held by employees is more Balanced and Relational, however where commitment and obligation is concerned it's more of the Transactional contract. It can be added that even though they are getting aspirations from the company, yet they don't feel emotionally attached with the company. It is further emphasized that lack of motivation, lack of leader's transparency; less support for management are the reasons for less emotional attachments. Inspite, of all employees seem to be happy with the savings they could make with this employment. Content analysis also reveals that they are in the industry purely because they want to learn and know this industry and later can start their own. In addition to that as the opportunities of growth in the sector are less, the data showed a less turnover ratio than the wide expected belief that the turnover in the sector is high.

\section{Conclusion}

Psychological contracts are formed on the basis of trust; the strength of a psychological contract depends on mainly on two factors: Internal and External. The internal factor is Individual own perception which is built by his/her cultural surroundings' and external, how fair an individual finds an organization is in fulfilling its perceived obligations above and below the formal contract of employment. This, in turn determines the individuals' commitment to the organization and contrast to it if it gets violated, job-satisfaction depletes. Then the choice to be in the employment relation remains purely with the individual employee. The stronger the employee and employer build up their creditability they tend to rely more and more on each other and give rise to long and lasting relationship. Psychological contract remains strong till it suits the individuals' Life-Orientation and this leads to a commitment to be or not to be a part of the organization. As the world evolves and sees a change in the paradigm a change that is evident in the organizations structure, their strategy, the job shift, the new work cult needs to focus on a better return on relationship (ROR) then on return on investment (ROI). Psychological Contract paves the way for a healthy and fruitful relationship between the employee and employer, which helps in the sustenance of the organization.

\section{Reference}

Alexandra, A. \& Staffelbach, B. (2011). Insecurity after restructuring: Is it all about trust in one's employer and one's employability?, Universität Zürich in house publication. www.business.uzh.ch /professorships/.../Diskussionspapier_Nr_18.pdf.

Anderson, N. \& Schalk, R. (1998). The psychological contract in retrospect and prospect. Journal of Organisational Behavior, 19, 637-647.

Amidah. B. ( 1998). Forms of Prayer for Jewish Workshop, The assembly of Rabbis of the Reform Synagogues of Great Britain, The Reform Synagogues of Great Britain, London, 145.

Argyris, C. (1960). Understanding Organisational Behaviour (Homewood, Illinois: The Dorsey Press Inc)

Bridges, W. (1994). The end of the job. Fortune - Sept 19 658, 62-74.

Bridges, W. (1995). JobShift : How to prosper in a workplace without jobs. St Leonards, N.S.W.: Allen \& Unwin.

Cooper C. L. (1999). The changing psychological contract at work. European Business Journal, 11, 115-118. 
Coyle-Shapiro, J. A. \& Kessler, I. (2000). Consequences of the Psychological Contract for the employment relationship: A large scale survey. Journal of Management Studies, 37(7), 903-930.

Cyril-van, D. V. (2004). The Psychological Contract; a big deal? A report submitted to Ministry of Defense The Hague, The Netherlands Behavioural Sciences Service Centre

Davidson, P. (2001). The Changing Nature of Psychological Contract in the IT industry, Research Paper in Human Resource Management, Kingston Business School.

De Meuse, K. P. \& Tornow, W. W. (1990). The tie that binds - has become very, very frayed! Human Resource Planning, 13, 203-213.

Donald, C. ( 2008), The Psychological Contract: The Development and Validation of a Managerial Measure, Doctoral work submitted to The University of Waikato.

Guest, D. E. (2004). The psychology of the employment relationship: An analysis based on the psychological contract. Applied Psychology: An International Review, 53(4), 541-555.

Gossett, M. L. (2006), Falling between the Cracks: Control and Communication Challenges of a Temporary Workforce, Management Communication Quarterly 2006 19, 376-415.

Handy, C. (1989). The Age of Unreason. Cambridge, MA: Harvard Business School Press.

Justin, A. \& Eisenberger, R. (2003). Perceived Organizational Support and Psychological Contracts: A Theoretical Integration, Journal of Organizational Behavior, 24(5), 491-509.

Levinson, D. J. (1979). The seasons of a man's life. New York: Ballantine Books.

O'Reilly, B. (1994). The new deal: What companies and employees owe one another. Fortune, 129, 44-51.

Patterson, F. (2001). Developments in work psychology: Emerging issues and future trends. Journal of Occupational and Organizational Psychology, 74, 381-390.

Robinson, S. L. (1996). Trust and breach of the psychological contract, Administrative Science Quarterly, 41, 574-599.

Rogers, R. W. (1994). The psychological contract of trust. Pittsburgh: Development Dimensions International.

Rousseau, D. M. (1989). Psychological and implied contracts in organizations. Employee Responsibilities and Rights Journal, 2(2), 121-139.

Rousseau, D. M. (1995). Promises in action: Psychological contracts in organizations. Newbury Park, CA: Sage.

Rousseau, D. M. (2000). Psychological contract inventory technical report. Retrieved March, 2002, from http://www.andrew.cmu.edu/user/rousseau/0_reports/pci.pdf.

Rousseau, D. M., \& Shperling, Z. (2003). Pieces of the action: Ownership and the changing employment relationship. Academy of Management Review, 28(4), 553-570.

Schein, E. H. (1965). Organizational Psychology. Englewood Cliffs, NJ: Prentice Hall

Shostak, A. B. (1993). The nature of work in the twenty-first century: Certain uncertainties. Business Horizons, November-December, 30-34.

Smithson, J. \& Lewis, S. (2000). Is job insecurity changing the psychological contract? Personnel Review, $29(6), 680-702$.

Thomas, D. C., Kevin, A. \& Ravlin, E. C. (2003). Cultural Variation and the Psychological Contract. Journal of Organizational Behavior, 24, 451-471.

Van Buren, H. J. (2000). The Bindingness of social and psychological contracts: Toward a theory of social responsibility in downsizing. Journal of Business Ethics, 25, 205-219.

ASSOCHAM Report on Majority of working couple inclined towards fast food, says survey (Metros family moving fast to "fast food") Saturday, January 01, 2011 http://www.assocham.org/prels /shownews.php?id=2699. 